\title{
The e-lang Project: Towards a Socio-Interactional Approach for Language Teaching and Learning
}

Catherine Jeanneau \& Christian Ollivier

Catherine.Jeanneau@ul.ie \& ollivier.reunion@gmail.com

\begin{abstract}
In this theoretical paper, we present an innovative pedagogical approach to language learning and teaching. This approach is based on a dialogical conception of communication and the principle that any human action and communication is determined by the social interactions within which it takes place. On the strength of this approach, we propose an extension of the usual typology of tasks in order to include what we call real-world tasks. The characteristics of this new type of tasks are then specified. Finally, we give a concrete example of a real-world task. Keywords: Language Learning and Teaching; Social Interaction; Tasks; e-lang Project; Digital Literacy
\end{abstract}

\section{Introduction}

The advent of digital technology has brought about many changes in our lifestyle, and the education sector is no exception to this change. The integration of new technologies in teaching and learning has led to the development of new pedagogical practices. As early as the 1990s, researchers started to report on these new practices and on the way they impact the teacher-learner relationship, highlighting that technology facilitates a student-centred approach (Bump, 1990; Chun, 1994; Kern, 1995).

New technologies also gained importance in the political discourse as they are viewed as fostering innovation in education (UE, 1999; 2000; 2013). Education and training policies rapidly followed suit, especially in Europe, where digital literacy became one of the key competences in education and for lifelong learning (UE, 2000; 2006). National policies also integrated digital skills in their educational framework. In Ireland for example, the Department of Education and Skills published the Digital Strategy for Schools 2015-2020 
which sets out clear directions to embed ICT tools in schools (both at primary and post primary levels) to realise the potential of digital technologies to enhance teaching and learning.

However, despite all these actions, recent studies and reports (Guichon, 2012, OECD, 2015) have highlighted that digital tools are still under-used in the classrooms. Furthermore, digital integration poses pedagogical challenges to practitioners who see their role being impacted upon (Laurillard, 2015) and some researchers even raise the question of the place of digital literacy in the educational system (Bergeron \& Péladeau, 2017).

The e-lang project, funded by the ECML (European Centre for Modern Languages), was initiated in response to some of these challenges. It builds on the findings and outputs of previous research and projects, especially those focusing on digital training for (language) teachers (for instance: Gee \& Hayes, 2011; Dudeney, Hockly \& Pegrum, 2013; ICT-REV, DIGICOMP, Digilanguagues ${ }^{1}$ ) but has also developed its own pedagogical framework which provides strong theoretical foundations to the initiative.

This theoretical paper will present the above-mentioned framework. After a short overview of the aims and objectives of the e-lang project, we will focus on its innovative aspect, which is outlined in the theoretical grounding of the project. The framework promotes a sociointeractional approach and the use of online technologies which combines interactional and cognitive dimensions for the teaching and learning of languages. A concrete example of a task which is based on this framework will also be presented.

\section{The e-lang project}

The e-lang project is one of the components of the wider ECLM programme entitled "Languages at the Heart of Learning". While the overall programme addresses major challenges in language education in ECML member states, e-lang concentrates on developing language learners' digital literacy by providing the basis for a teaching and learning methodology which integrates new technologies. The main focus of this project is therefore language pedagogy. The project promotes a digital integration based on an approach that combines online interactions with a critical use of digital tools and resources to develop linguistic and communication skills as well as intercultural skills and digital literacy. We 
The e-lang project: Towards a socio-interactional approach for language teaching and learning

understand digital literacy as the capacity to make an effective and critical use of digital technology as users and creators. ${ }^{2}$

This digital literacy development takes the shape of training modules for teachers and teacher trainers on a Moodle platform. It offers an innovative use of online technologies by combining interactional and cognitive dimensions. The modules developed as part of the project focus on the various communicative and language tasks (including reception, production, interaction, mediation) as well as on linguistic skills (i.e. lexical, grammatical, phonological) and intercultural competence. Each module includes a succinct review of the theoretical background of the field which is covered within the module and then provides a range of practical tasks to develop digital literacy in the said domain. It also suggests digital tools and resources for the implementation of the various tasks proposed within the module. This training is designed to help teachers in guiding learners to acquire the skills needed for an autonomous use of languages. Participants to the training are also encouraged to suggest their own resources and to give feedback on their own implementation of the various tasks presented in the project thus contributing to the development of the training content.

The overall training also presents a new type of tasks: real-world tasks. These tasks introduce a new set of interactional activities for learners and derive directly from the approach adopted as part of the project. This approach will now be discussed in more details.

\section{Presentation of framework: Towards a socio-interactional approach}

In the 1970s, Hymes pointed out that socio-cultural factors are shaping the way we learn to communicate and how we use languages. Indeed, we learn to recognise the "appropriateness" of our actions within our social context, we learn "when to speak, when not, and as to what to talk about with whom, when, where, and in what manner" (Hymes, 1972, p. 277).

In the 1980s and 1990s, many models of communicative competence (Bachman, 1990; Canale \& Swain, 1980; Coste, Courtillon, Ferenczi, Martins-Baltar, \& Papo, 1976; Moirand, 1982) also emphasised the social dimension of communication. However, these models all share the following features. They: 
The e-lang project: Towards a socio-interactional approach for language teaching and learning

- place social dimension at the same level as any other elements of communicative competence. In other words, social dimension does not feature more prominently than any other aspects of this competence;

- often equate social dimension to socio-cultural / socio-linguistic elements, leaving intersubjectivity out of the equation.

The CEFR - for example - defines "communicative language competence [...] as comprising several components: linguistic, sociolinguistic and pragmatic" (Council of Europe, 2001, p. 13). It is worth noting that the social component is confined to the sociolinguistic dimension.

Even if the CEFR action-oriented approach places a large emphasis on "social agents" and the "social context" within which tasks are carried out (Council of Europe, 2001, p. 9), this refers to social and cultural norms rather than interpersonal relations as the latter are barely mentioned in the framework.

This vision does not fully reflect the way in which we envisage communication in real life. Following the school of thought of language philosophers such as Grillo (2000) and Jacques $(1979,1985,2000)$, we consider that any action or communication (viewed here as a form of human action) is largely conditioned by the social interactions within which it takes place. We define "social interactions" as the dynamic (i.e. constantly evolving) social relationship that exists between the various people involved in any action. In other words, action is determined primarily by the social relationship between participants and this relationship can evolve as a result of the actions.

Similarly, we consider that linguistic communication, as a dialogic and interpersonal process, is first and foremost influenced by social relationships. In our approach, the constraints of interpersonal exchanges supersede socio-cultural norms, that is, "abstract norms which dictate communicative practices in general"3 (translated from Bouvier, 2000, p. 72).

However, we do not reduce communication competence to that sole dimension. The subcompetences (linguistic, sociolinguistic, pragmatic...), which are components of models 
developed since the 1970 s, remain relevant. But we pose the primacy of social interaction over other dimensions. We therefore state that the activation of other components is determined by the interpersonal social interaction.

Our approach is in line with the wider trend of rethinking the unidirectional models of communication (Kerbrat-Orrecioni 1986, 2005). In these models, the sender encodes a message and the receiver has to decode it. The receiver is therefore limited to a decoder role which must reconstitute the original message (see Shannon, 1948 or Jakobson 1960).

Communication is a much more complex phenomenon. We consider that the construction of meaning involves all the partners of communication and that all communication is thus coenunciation. For us,

- the production and understanding of discourse are interrelated and indissociable activities;

- the meaning of any statement is shaped by the social interaction at play.

Talking is not saying something to someone but rather saying something together about something (Grillo, 1997, p. 63). In such a model, there is not a sender on one side and a receiver on the other, both being active in turns. Each person involved in the communication process is "both sender and receiver, not only in successive stages, but at the moment of enunciation"4 (translated from Culioli, 1999, p. 47). Communication partners, as coenunciators or co-speakers, co-construct meaning.

Being a proficient communicator implies that we can produce a message that we feel the other(s) should understand. As Jacques stated: "my ears are doing the talking" 5 (translated from Jacques, 2000, p. 63). It means that we always have to keep our interlocutor(s) in mind no matter what we do or say. The social ties linking us to the others in the interaction determine any communication and/or action.

The socio-interactional approach therefore aims to place social interactions at the centre of its task definition. The aim is to enable learners to learn to take into account these social 
interactions when acting and interacting in the target language. They will thus become aware of the crucial nature of these interactions and develop strong communication skills. By carrying out tasks within varied social interactional contexts, learners will be able to develop a strong communication competence. In other words, they will learn to act and communicate in an appropriate way within various interpersonal relationships.

However, social interactions are often only partially considered in teaching and learning situations. This is even more true when the intended target of the task is simulated. In teaching and learning scenarios, teachers mostly focus on asking learners to simulate the interactions of the main protagonists of the task. But the interactions with the intended target of the tasks - the final recipient(s) of the product - are partially or completely omitted. When students - for example - plan the programme of a trip for a simulated group of people, the interactions between them may be close to those between employees of a travel agency, but they will not be able to interact with the group or its representatives since they do not exist. Students can therefore only partially take them into consideration. They may even go as far as to ignore them, since they are not really the final recipients of the programme, which very often only the teacher will read and evaluate.

In real life, there may be no language interactions between the actors and the final recipient(s). Nevertheless, the social interactions between the actors of the task and the recipients always play a decisive role in the completion of the task. If - for example - a group prepares a party for a friend's birthday, even if the friend does not participate in the preparatory activities, $\mathrm{s} / \mathrm{he}$ has a strong invisible presence and plays a pivotal role in the decision making process. The task is therefore determined by the social interactions with the final recipient(s) and by the social interactions between the people directly involved in the preparation.

In a socio-interactional approach, both the final recipient(s) and the purpose of the task are therefore real. In other words, in a socio-interactional approach, both the social interactions and the action are authentic. 
This is why we are considering extending the typology of tasks to "real-world tasks" in order to extend the interactional network beyond the learner-teacher group. The e-lang project focuses on tasks that can be carried out on the participative web, often referred to as web 2.0.

\section{Tasks and real world}

As Ellis (2017a, p. 508) states, when it comes to tasks and task based learning "the key question [...] is whether 'task' should be defined narrowly in terms of real-world activities or more generically in terms of activities that are purely pedagogic in nature". Even if advocates of task based learning do not agree on the articulation between target tasks and pedagogic tasks, they all include both in their task typologies (Ellis, 2017b).

Typologies of tasks refer to real life and define two main types of tasks: tasks which reflect real life and tasks which are indirectly related to real life. Real-world tasks remain excluded from the educational context. When some researchers use the term (Long, 2016 for example), it does not mean that tasks are completed in the real-word, but that they mirror real world tasks. Thus, Nunan, in 1989 and at the very beginning of his book published in 2004, proposes a fundamental typology distinguishing between real-world tasks and pedagogical tasks. The former refer to the use of language in the world outside the classroom, while pedagogical tasks are carried out inside the classroom:

I will draw a basic distinction between what I will call real-world or target tasks, and pedagogical tasks: target tasks, as the name implies, refer to uses of languages in the world beyond the classroom, pedagogical tasks are those that occur in the classroom. [...] When they are transformed from the real world to the classroom, tasks become pedagogical in nature (Nunan, 2004, p. 1s.).

According to Nunan, real-world tasks have nothing to do in the language class, it is even, impossible to carry out such a task in a pedagogical situation. A real-world task can only be "a communicative act we achieve through language in the world outside the classroom" (Nunan, 2001). If such a task comes within the walls of the classroom, it automatically becomes a 
pedagogical task. Nunan thus meets Widdowson's (1994) criterion of "non-transferability" of authenticity from the real world to the classroom.

Once real life is excluded from the classroom, Nunan (2001) distinguishes between two main types of pedagogical tasks. Rehearsal tasks are "a piece of classroom work in which learners rehearse, in class, a communicative act" since activation tasks are "a piece of classroom work involving communicative interaction, but NOT one in which learners will be rehearsing for some out-of-class communication. Rather they are designed to activate the acquisition process".

The distinction made by several French-speaking researchers (Demaizière \& Narcy-Combes, 2005; Guichon, 2006; Narcy-Combes, 2005) largely echoes the distinction between rehearsal and activation tasks. Narcy-Combes (translated from 2005, p. 167) refers to "more global macro-tasks and micro-tasks that promote training"6. For Guichon (translated from 2006, p. 54), macro-tasks are "a global learning project in which learners are led to process written or oral information in L2 in order to construct a written or oral meaningful product" and "put the participant in a realistic situation in which they will have to use the target language (or at least it brings him or her closer to the activities of life outside school" (2006, p. 80). A microtask is a "cognitive activity centred on a specific linguistic, pragmatic or socio-cultural aspect" (Guichon, 2006, p. 79). Demaizière and Narcy-Combes (translated from 2005, p. 50) also see macro-tasks as "a set of actions which forms a 'staging' of reality", while micro-tasks are "more contained and less realistic". The importance of both meaning and realism is emphasized by all these researchers.

The CEFR also establishes two types of tasks which fit these categories. On the one hand, we find "'real-life', 'target' or 'rehearsal' tasks". These are chosen "on the basis of learners' needs outside the classroom, whether in the personal and public domains, or related to more specific occupational or educational needs." On the other hand, we are presented with tasks that are "specifically 'pedagogic'". These tasks "are only indirectly related to real-life tasks and learner needs, and aim to develop communicative competence". (Council of Europe, 2001, p. 157). 
The e-lang project: Towards a socio-interactional approach for language teaching and learning

Finally, we should add that for some scholars, the word "tasks" (on its own) should only refer to target tasks and relate to real-world activities. According to Long (2016) for example, tasks are "the real-world communicative uses to which learners will put the $\mathrm{L} 2$ beyond the classroom-the things they will do in and through the L2". Long calls these tasks "real-world tasks", but it is obvious that this kind of tasks are not completed in the real world, but only prepare for language use beyond the classroom in the future - Long uses the future tense ("will do").

In the above-mentioned classification, which distinguishes between rehearsal tasks and pedagogical/activation tasks, two elements are essential:

a) the repeated reference to the proximity (or not) with the real world (Council of Europe, 2001; Demaizière \& Narcy-Combes, 2005; Nunan, 2001, for example) as a way to delineate between types of tasks;

b) the reference to real life is associated explicitly or implicitly with its exclusion from the classroom. Rehearsal tasks only reflect "real life use" of language (Council of Europe, 2001, p. 156), they "mirror" (Nunan, 2001; Richards, 2006), "parallel" (Clarke \& Silberstein, 1977, p. 51) or "correspond" to tasks carried out in real life.

Authenticity is thus largely excluded from classroom scenarios. Widdowson stated that "the language is only authentic in the original conditions of its use, it cannot be the classroom. The authenticity is non-transferable" (1994, p. 386). The purpose here is by no means to deny the specific authenticity of the teaching and learning situation or the fact that it belongs to the real world, but to recall the discrepancy that usually exists between language use in the teaching and learning context and in the world beyond the classroom walls. As a result, if we want to help learners develop the skills necessary to use the language and overcome the constraints imposed by the specific interactional situation that the language classroom represents, we must consider the opportunities for learners to use the language outside any learning context. The aim is then to enable learners to act as individuals and language users and not solely as language learners. Real-world tasks represent one of these opportunities. 
The e-lang project: Towards a socio-interactional approach for language teaching and learning

\section{Real-world tasks}

In this section, we present our definition of real-world tasks, (RWT henceforth) and their specificities:

- primordial importance of social interactions,

- authenticity of language use and communication objective,

- existence of the task prior to any pedagogical action,

- evaluation within the social interaction.

We define real-world tasks as tasks carried out within social interactions that go beyond the class group and the overall educational world. In French, these tasks are called "tâches ancrées dans la vie réelle" (tasks anchored in real life). We are making a reference to 'anchorage' because, while completing these tasks, learners are linked both to the classroom and to the outside world through their social interactions with people on the web 2.0.

Real-world tasks make learners interact with "real" people outside the educational system. Students address Internet users within social interactions defined by the rules, norms and etiquette of the websites as well as by the interpersonal dimension. In some cases, the intersubjective dimension is essential, for example on discussion forums. On other websites, social interactions will be mostly determined by explicit or implicit social rules. This is the case on Wikipedia for example. Participants act in accordance with readers' expectations, which are coincidentally generally also their own expectations, since contributors are usually also users of the encyclopaedia. So their postings are guided by what they would like to find.

The social dimension is also present at the evaluation level, as it is carried out by other Wikipedians and may lead to exchanges in the discussion section of the articles. Wikipedians have also drawn up guidelines of good behaviour in which good personal interactions are promoted. The "Please do not bite the newcomers" page devoted to welcoming novice contributors is significant: for example, it reminds that Wikipedians "must treat newcomers with kindness and patience-nothing scares potentially valuable contributors away faster than hostility". Social evaluation by the community adresses two of the prominent issues in task based language assessment: "the authenticity of criteria for evaluating task 
The e-lang project: Towards a socio-interactional approach for language teaching and learning

performance" and the difficulty to design assessment tasks that simulate adequately "tasks and associated language use contexts" (Norris, 2016, p. 239).

In real-world tasks, the primary objective of language use is the same for language learners as it is for any other Internet users. Learners are language users and they use language to communicate. As a result, language learning is not the primary focus. The intention is elsewhere: to share knowledge or experience (a recipe for instance); to solicit opinions or advice (on how to do something for example); to share news, common interests... Hanna and Nooy's experience of students participating on Le Monde's forums is instructive (Hanna \& de Nooy, 2003). The students who were most welcomed were the ones who came to the forums to debate and not the ones whose primary intentions were to improve their French.

In the case of real-world tasks carried out on the web 2.0, the task exists before any pedagogical activity. It is not designed by the teacher or a textbook author, but derives from the nature and purpose of the site. Wikipedia thus proposes to contribute to the construction of an encyclopaedia, or a forum to discuss specific topics. The teacher invites learners to participate in the tasks $\mathrm{s} /$ he has identified on these platforms.

Finally, the evaluation takes place within the social interaction in which the task takes place. It is therefore carried out by the people with whom the learners, as language users, interact socially. On Wikipedia, for example, the Wikipedians judge the quality of the contributions and even correct language errors. On a cooking forum, the evaluation occurs through feedback from forum members: most of the time, they thank the contributors or comment on the quality of the dish, or even suggest variations... A social evaluation is given according to the implicit or explicit criteria related to the interactions at play. In any case, the teacher is neither the recipient nor the evaluator of the learners' contributions.

The role of teachers is evolving. In our approach, teachers do not design the tasks, which preexist on a web 2.0 platform prior to their teaching and learning use. The task is defined by the owners of the site and/or the community. Thus, one of the key tasks of the teacher is to identify websites where interesting real-world tasks can be carried out and to design teaching and learning scenarios around theses tasks. They also have to convince learners to engage 
with the tasks. Indeed, in order to prevent learners from considering the task as just educational and subverting the aim of the task, they should not be forced to carry out the task. They should complete the tasks because they recognize the potential social value of their contribution and should be aware that what they are doing is something "real" that can be useful for other people. Finally, as tasks are happening in and outside the classroom at the same time, teachers can facilitate their implementation by helping learners to develop the needed knowledge and competence.

\section{Example of a real-world task}

In order to make our theoretical framework more comprehensible, we propose an example of a real-world task below. This task is fully detailed and explained in the elang pedagogical framework (Ollivier, forthcoming).

Participating in a crowdsourced travel guide (WikiVoyage: https://www.wikivoyage.org/ or WikiTravel: http://wikitravel.org) is a typical real-world task. Students can share information with the numerous visitors of the platform in their target language. They can post relevant details about their own town or country. By doing this, they address a real public potentially interested in the information they can provide and have to keep this in mind during the task completion. In order to help learners understand the social interactions involved and the constraints associated with them, they may be asked to take into consideration their own expectations when visiting such a website and to read the pages that explain the social rules of the site. This will guide them while choosing the content they want to share, but will define how they should write their contributions. In a socio-interactional approach, it is essential that learners become aware that their productions have to fulfil the explicit and implicit social requirements of the site.

Beyond this socio-interactional dimension, these tasks are interesting because learners can actively participate in the production of relevant information on the web 2.0 and can become aware of how information is generated and managed on a participatory site. This type of tasks enables learners to develop not only communication and action skills, but also digital literacy. 
The e-lang project: Towards a socio-interactional approach for language teaching and learning

\section{Conclusion}

Before drawing our final conclusions, we would like to stress that we do not advocate that real-world tasks are the only tasks presented to learners. Research has proven the benefits of target and pedagogical tasks (Ellis, 2017b; Samuda \& Bygate, 2008; Skehan, 2014) as well as the necessity to provide "a safe place (the classroom) in which students may experiment" (Wigglesworth \& Yates, 2007, p. 799). Therefore, real-world tasks should only be offered as an additional type of tasks that give the opportunity to experience communication in all its interactional dimensions. Carrying out only real-world tasks would over-expose students and present too much risk and stress for them.

The innovative aspect of the socio-interactional approach adopted for the elang project (http://www.ecml.at/e-lang) is the emphasis which is placed on social interactions. The approach views learners as knowledgeable individuals and as language users and, as such, facilitates ways for learners to share their knowledge in the target language with other web users. When they post contributions on sites such as Wikitravel, they are not just knowledge consumers but also knowledge co-creators. When answering questions on a travel site, they share their personal experience with interested parties. Real-world tasks allow them to show their ability and exercise their right to speak in the target language outside the educational boundaries. In doing so, learners are empowered but also they truly engage in social interactions using some of the scarcely explored potential of digital technologies.

\section{References}

Bachman, L. F. (1990). Fundamental considerations in language testing. Oxford: Oxford University Press.

Bergeron, R. \& Péladeau, P. (2017). Quelle place pour le numérique à l'école ? Relations, 789. $12-13$.

Bouvier, A. (2000). Pragmatique et rhétorique philosophiques versus point de vue argumentativiste en sciences sociales. In P. Livet (ed.), L'argumentation: droit, philosophie et sciences sociales (pp. 43-100). Paris: L'Harmattan.

Bump, J. (1990). Radical changes in class discussion using networked computers. Computers and the Humanities, 24(1-2), 49-65. https://doi.org/10.1007/BF00115028 
Canale, M., \& Swain, M. (1980). Approaches to communicative competence. Singapore: SEAMEO Regional Language Centre.

Chun, D. (1994). Using computer networking to facilitate the acquisition of interactive competence. System, 22(1), 17-31.

Clarke, M. A., \& Silberstein, S. (1977). Toward a realization of psycholinguistic principles in the ESL reading class. Language Learning, 27(1), 135-154.

Coste, D., Courtillon, J., Ferenczi, V., Martins-Baltar, M., \& Papo, É. (1976). Un niveau-seuil. Strasbourg: Conseil de l'Europe.

Council of Europe. (2001). Common European framework of reference for languages : learning, teaching, assessment. Cambridge, U.K.: Press Syndicate of the University of Cambridge. Council for Cultural Co-operation. Education Committee. Modern Languages Division (Strasbourg).

Culioli, A. (1999). Pour une linguistique de l'énonciation. Tome 2, Formalisation et opérations de repérage. Gap; Paris: Ophrys.

Demaizière, F., \& Narcy-Combes, J.-P. (2005). Méthodologie de la recherche didactique: nativisation, tâches et TIC. Alsic, 8(1), 45-64. https://doi.org/10.4000/alsic.326

DES (2015). Digital Strategy for Schools 2015-2020: Enhancing teaching, learning and assessment. Dublin: Department of Education and Skills.

Dudeney, G., Hockly, N., \& Pegrum, M. (2013). Digital Literacies, Research and Resources in Language Teaching. London: Routledge.

Ellis, R. (2017a). Position paper: Moving task-based language teaching forward. Language Teaching, 50(4), 507-526. https://doi.org/10.1017/S0261444817000179

Ellis, R. (2017b). Task-based language teaching. In S. Loewen \& M. Sato (Eds.), The Routledge handbook of instructed second language acquisition (pp. 108-125). New York; London: Routledge.

Gee, J.P. \& Hayes, E.R. (2011). Language and Learning in the Digital Age. Abingdon, Oxon: Routledge.

Grillo, E. (2000). Intentionnalité et signifiance : une approche dialogique. Bern; Berlin; New York: Peter Lang.

Guichon, N. (2006). Langues et TICE : méthodologie de conception multimédia. Paris: Ophrys.

Guichon, N. (2012). Integration of ICT in Language Teaching. Paris: Didier.

Hanna, B. E., \& de Nooy, J. (2003). A funny thing happened on the way to the forum: Electronic discussion and foreign language learning. Language Learning \& Technology, 7(1), 7185. Retrieved from http://www.lltjournal.org/item/2418

Hymes, D. H. (1972). On communicative competence. In J. B. Pride \& J. Holmes (eds), Sociolinguistics. Selected Readings (pp. 269-293). Harmondsworth: Penguin.

Jacques, F. (1979). Dialogiques: recherches logiques sur le dialogue. Paris: Presses universitaires de France.

Jacques, F. (1985). Dialogiques 2. L'espace logique de l'interlocution. Paris: Presses Universitaires de France.

Jacques, F. (2000). Écrits anthropologiques: Philosophie de l'esprit et cognition. Paris: L'Harmattan.

Jakobson, R. (1960). Linguistics and poetics. In T. A. Sebeok (ed.), Style in language (pp. 350377). New York; London: The technology Press of Massachussetts Institute of Technology; John Wiley and Sons. 
Kerbrat-Orecchioni, C. (1986). " Nouvelle communication » et " analyse conversationnelle ». Langue française, 70(1), 7-25. https://doi.org/10.3406/lfr.1986.6368

Kerbrat-Orecchioni, C. (2005). Le discours en interaction. Paris: Armand Colin.

Kern, R. (1995). Restructuring classroom interaction with networked computers: effects on quantity and characteristics of language production. Modern Language Journal, 79(4), 457-476.

Laurillard, D. (2015). How should professors adapt to the changing digital education environment?. In E. De Corte, L. Engwall, U. Teichler (Eds.), Emerging Models of Learning and Teaching in Higher Education: From Books to MOOCS? Stockholm: Wenner-Gren.

Long, M. H. (2016). In defense of tasks and TBLT: Nonissues and real issues. Annual Review of Applied Linguistics, 36, 5-33. https://doi.org/10.1017/S0267190515000057

Moirand, S. (1982). Enseigner à communiquer en langue étrangère. Paris: Hachette.

Narcy-Combes, J.-P. (2005). Didactique des langues et TIC: vers une recherche-action responsable. Editions OPHRYS.

Norris, J. M. (2016). Current uses for task-based language assessment. Annual Review of Applied Linguistics, 36, 230-244. https://doi.org/10.1017/S0267190516000027

Nunan, D. (1989). Designing tasks for the communicative classroom. Cambridge; New York: Cambridge University Press. Retrieved from https://archive.org/details/ilhem_20150321_1843

Nunan, D. (2001). Aspects of Task-Based Syllabus Design. Retrieved 16 July 2012, from http://www3.telus.net/linguisticsissues/syllabusdesign.html

Nunan, D. (2004). Task-based language teaching. Cambridge; New York: Cambridge University Press.

OECD. (2015). Students, Computers and Learning. Making the Connection - Main results. Paris: PISA, OECD.

Ollivier, C. (in press). Digital literacy for the teaching and learning of language. Towards a socio-interactional approach. (C. Jeanneau, Trans.). Strasbourg: Editions du Conseil de l'Europe.

Richards, J. C. (2006). Communicative language teaching today. New York: Cambridge University Press.

Samuda, V., \& Bygate, M. (2008). Tasks in second language Learning. London: Palgrave Macmillan. https://doi.org/10.1057/9780230596429 5

Shannon, C. E. (1948). A mathematical theory of communication. The Bell System Technical Journal, 27, 379-423.

Skehan, P. (Ed.). (2014). Processing perspectives on task performance. Amsterdam; Philadelphia: John Benjamins Publishing Company.

Union européenne (1999). Communication du 8 décembre 1999, concernant une initiative de la Commission pour le Conseil européen extraordinaire de Lisbonne des 23 et 24 mars 2000: eEurope - Une société de l'information pour tous [COM(1999) 687]. http://eur-lex.europa.eu/legal-content/FR/TXT/?uri=LEGISSUM\%3AI24221

Union européenne (2000). eLearning - Penser l'éducation de demain. http://eurlex.europa.eu/legal-content/FR/TXT/?uri=LEGISSUM:c11046

Union européenne (2006). Recommandation du parlement européen et du conseil du 18 décembre 2006 sur les compétences clés pour l'éducation et la formation tout au long de la vie (2006/962/CE) http://eur-lex.europa.eu/legalcontent/FR/TXT/PDF/?uri=CELEX:32006H0962\&from=EN 
Union européenne (2013). Communication de la commission au parlement européen, au conseil, au comité économique et social européen et au comité des régions. Ouvrir l'éducation: les nouvelles technologies et les ressources éducatives libres comme sources innovantes d'enseignement et d'apprentissage pour tous [COM/2013/0654]. http://eur-lex.europa.eu/legalcontent/FR/TXT/?qid=1389115469384\&uri=CELEX:52013DC0654

Widdowson, H. G. (1994). The Ownership of English. TESOL Quarterly, 28(2), 377-389.

Wigglesworth, G., \& Yates, L. (2007). Mitigating difficult requests in the workplace: What learners and teachers need to know. TESOL Quarterly, 41(4), 791-803.

1 ICT-REV is a project of the European Centre of Modern Languages of the Council of Europe dealing with the "use of ICT in support of language teaching and learning". DIGICOMP is an Erasmus+ Key Action 2 project which focused on developing digital competences for teachers via an e-learning platform. Digilanguages is a project funded by Ireland's National Forum for the Enhancement of Teaching \& Learning. One of its aims is to provide online resources and activities contributing to the development of Digital Literacies for language teaching and learning

2 For more details, see Ollivier (2018).

3 "Normes abstraites gouvernant la pratique de la communication en général".

4 "à la fois émetteur et récepteur, non point seulement en succession, mais au moment même de l'énonciation"

5 "Ce sont mes oreilles qui te parlent".

6 "Macro-tâches plus globales et micro-tâches qui favorisent l'entraînement". 